\title{
SELF-ORGANIZATION IN SOCIAL SYSTEMS: ESSENCE, FEATURES AND PURPOSEFUL NATURE
}

\author{
(C) KARALASH, YULIIA \\ Zhytomyr Ivan Franko State University (Ukraine, Zhytomyr) \\ E-mail: julia.karalash@gmail.com, ORCID: https://orcid.org/ 0000-0001-6537-3543 \\ Zhytomyr Ivan Franko State University, Bolshaya Berdichevskaya, 40, Zhytomyr, \\ Ukraine, 10008
}

The urgency of the research of self-organization of social systems is, firstly, due to the incompleteness of the social-humanitarian theory of this concept and, secondly, to the objective necessity to increase the level of organization and the orderliness of social systems, their controllability through self-organization as a way of overcoming the grand and local challenges. The aim of this paper is to investigate the essence, the features and the purposeful nature of self-organization as a social activity, which is aimed to order the social systems. It is specially noted that multidisciplinary methodological tools in socio-humanitarian researches, with Mathematics at their core, are not sufficient for revealing the universal essence of selforganization and its characteristic features in the social systems. Therefore, it has been suggested to supplement the synergetic conceptualization by using the heuristic potential of the third-generation system method as a methodological basis for studying the essence and peculiar properties of self-organization of social systems. It has been allowed to consider the groundwork of the second-order cybernetics, the theories of living systems and the emergence. It is pointed out that a citizens' initiative is a basic form of self-organization in the social systems and its elementary action. The paper presents the differences between a civil initiative, as affective and traditional unconscious action, and a citizens' initiative whose emergent effect is the individual's formulation of goals. It is specially noted that citizens' initiative streamlines social systems and is differ from the spontaneity of civil initiatives. It is concluded that the proposed interpretation of self-organization of social systems and citizens' initiative as its structural element allows to understand the mechanism of quality upgrading of self-organization and the controllability of social systems more deeply. It is of particular importance in the context of overcoming the socio-economic crisis and pandemic, searching for global challenges solutions, returning the personality to Ukraine on the global stage with the prospects for democratization of the whole socio-political system and joining the number of developed countries.

Key words: social systems, self-organization, circular causality, emergence, aims, civil initiatives, citizens' initiatives.

Introduction. Since the middle of the 20th century the popularity of the discourse of self-organization in the socio-humanitarian studies is very high. It indicates, at least, its heuristic potential, on the one hand, and the necessity for social theories of macrolevel in the achievements of natural sciences, on the other one. In addition to the fact that the concept of selforganization is interesting theoretically, the scientists observe its importance for the practice under current conditions. Thus, Russian researcher of self-organization in society I. Zhuravl'ova writes: 
«Expansion of theoretical and empirical knowledge about the content and the strategies of social practices of self-organization in the conditions of formation the society of knowledge is an urgent task of the socio-humanitarian studies» [1, p. 30].

As the level of orderliness, the possibilities of the collective of people, their influence and «weight» in the social relations, the ability to solve certain tasks increase, the question of controllability of social systems in the conditions of necessity of returning the personality to Ukraine on the global stage with the prospects for inclusion to the top ten world leaders, becomes of present interest. In this context, one of the ways of overcoming the challenges facing the citizens of our country, is their selforganization.

Analysis of literary data and resolving the problem. The most authoritative researchers of selforganization and the related concept are the representatives of the Brussels (I. Prigogine, I. Stengers, P. Glansdorff, G. Nicolis) and Stuttgart (H. Haken and others) schools. Selforganization in general and selforganization of social systems are fundamentally represented in monograph series of the international publication «Springer»: «Understanding Complex Systems» and «Springer Series in Synergetics». More than 60 volumes have been published within this periodical. The processes of appearance of new integral qualities of systems, the order formation are considered in the articles of such researchers as $\mathrm{M}$. Eigen, E. Laszlo, F. von Hayek, C.
Fuchs, W. Hofkirchner, T. Negru, K. Mainzer, R. Steigerwald, Tea Golob \& Matej Makarovič, G. Degli Antoni, J. Schenk, S. Kauffman, A. Mikhailov, J.S. Wassenaar, M. Chorąży, J.K. de Vree and others.

Such scientists as V. Arshynov, V. Budanov, V. Vasyl'kova, I. Zhuravl'ova, YE. Knyazyeva, S. Kurdyumov, V. Smyrnov, V. St'opin, H. Ruzavin, V. Tuzov, V. Shalayev have made the significant contribution to the study of self-organization.

Such Ukrainian scientists as L. Bevzenko, I. Dobronravova, I. Snehir'ov, N. Kochubey and others have begun the investigations of selforganization and have given the social interpretation to it. Various aspects of self-organization are also described in the scientific works of $\mathrm{V}$. Andrushchenko, V. Budz, V. Voronkova, L. Horbunova, O. Dz'oban', D. Kozobrodova, V. Kremen, A. Matiychyk, V. Nadurak, I. Prybytkova, V. Rossokha, N. Spytsia, YE. Khodakivs'ky and others. The incompleteness and fragmentarity of the theory of selforganization, its application to the social systems, require the attention of the scientists, their new views and unexpected ideas. There is a need to refresh the theory, to explore the contradictions and to formulate the questions, that can give the impulse for further development.

The aim of the study is to investigate the essence, the features and the purposeful nature of selforganization as a social act, which is aimed to order the social systems

Linearity. Self-organization arises as a universal process, which belongs 
to all structural levels of movement, occurs in the systems of any qualitative nature - physical, technical, chemical, biological and social. T. Negru has considered the nature of self-organization and stated: «According to the current research self-organization is a ubiquitous process, which can be found all over in nature both in inanimate forms, and in the realm of living system $)[2, \mathrm{p}$. 218]. At the social level of the universal concept it is not possible to deny the phenomena of selforganization. The Law of Ukraine «On Bodies of Self-Organization of the Population» is a peculiar proof of the existence of self-organization phenomena in the society and its legitimation [3]. This law fixes a wide range of the activities of citizens under its jurisdiction, but it does not define the concept of «selforganization», which is an indirect sign of lack of high-quality social theory of self-organization.

Self-organization answers the question about the source of changes. Self-changes occur without external interference through the usage of the resources of changing system. $\mathrm{H}$. Haken notes: «... system can spontaneously form structures without specific interference from the outside, a phenomenon called selforganization» $[4$, p. 9]. Or, N. Luhmann gives the figurative expression: «The system emerges etsi no daretur Deus [even if God doesn't exist $] \gg[5$, p. 105].

In the specialized literature, a more complete definition of selforganization has become widely known. Thus, in his introduction to the materials of the International Conference on Synergetics (Berlin, 1983), H. Haken writes: "According to its definition, synergetics deals with systems composed of many parts which can form spatial, temporal or functional structures on macroscopic scales» $[6$, p. 1 , emphasis is added by the author of the paper]. Synergetics, according to the author of the term, raises the questions quite broadly, in the context of the search for basic principles of ordering the systems of different nature, including social ones. «The fact that spatial, temporal or functional structures are observed in a variety of fields may not be reason enough, however, to bring together scientists from all these disciplines. Rather one has to ask whether these phenomena are based on similar common principles. This was a question I asked more than 25 years ago, when I suggested to studying these phenomena within an interdisciplinary field that I called Synergetics, a name taken from the Greek, meaning, the science of cooperation» $[4$, p. 9].

For the foregoing reasons, for many researchers of self-organization in the social systems the common feature is interpreting these processes as some collective activities, social practices, collective dynamics. Thus, I. Dobronravova, one of the first Ukrainian researchers of selforganization, states: «The word "selforganization" clearly shows its meaning, corresponding to social practices, that promotes their awareness» [7, p. 192].

Synergetic at the level of researches of the phenomena of self- 
organization of social systems reflects the behavior of social elements using methods based on Mathematics, and which are characterized as quantitative ones. This understanding is extrapolated to social systems and tends to be generically called as structural functionalism. Its essence is characterized as a logical and mathematical, linear understanding of social systems, and the focus of the researches is on the rigid functional (cause and effect) dependence. The elements of social systems are regarded here as equivalents and of equal quality, and are corresponded to basic mathematical concepts (number, point). The mathematical order acts as a unification, the order of homogeneous equivalent units masses, and is represented by laws of large numbers, Statistics. In social systems, the unification leads to collectivism as impersonality system, where the qualitative specifics of social systems, both at the elementary level (at the level of the individual) and at the level of the whole (society) are not taken into account.

In this context, a group of researchers of self-organization states that a review is necessary: «Some applications of these ideas in the domain of the human sciences, where modelling has, on the whole, been somewhat unsuccessful in planning and policy decisions in the real world of human affairs» [8, p. 150].

Indeed, when modeling network traffic (K. Nagel, S. Rasmussen, L.C Barrett), pedestrian crowds (D. Helbing, P. Molnar), the formation of public opinion (H. Haken), space selforganization of population (I.
Prybytkova) and urban systems (R. White, G. Engelen) it is the fixation of the movement of some mass of identical units, where the movement is the simplest and mechanical one. This is the way how a mechanistic view of social systems is realized, where people are seen as identical elements, and their individual qualities (mental, intellectual, value, cultural differences) are important and determinative factors of social development, but they are ignored.

Through the formalism, synergetics is more exact and accurate science, and is characterized by wellordered theory that sets the tone for «not strict» socio-humanitarian studies. The specific scientific problems of socio-humanitarian studies tends to the ethical (V. Nadurak), psychological (I. YershovaBabenko), educational (L. Horbunova), cultural (A. Svidzyns'kyy, I. Donnikova) application of the concept of selforganization. Self-organization is interpreted as the basis of historical development (YE. Pylypko) and political stability (I. Horokhovs'kyy), and as a mechanism of social evolution (A. Lebid', O. Naumkina). According to V. Voronkova, selforganization at the social level appears as «...independent formation of social relations which is carried out without external purposeful programming», where «the substantive basis ... is the cooperative activity of individuals, as a result of which the structures are created that represent the complex of functional institutes in a certain order including the individuals, groups, communities»» 
[9, p. 31]. Another researcher L. Bevzenko understands the social selforganization as integration processes that are "closely related to social cohesion, solidarity, consolidation», as well as the ways of their realization and formation [10, p. 50].

It is specially noted that selforganization within the organization, is a process of ordering ( $\mathrm{V}$. Andrushchenko [11]) and as $M$. Boichenko said, is the development of abstract ideas about the principles of social order in the classical, conservative philosophical dimension [12, p. 74]. The researchers define self-organization as a type of organization and a movement towards increasing the state of being organized and consider it in terms of managerial concepts, sociology and management (N. Spytsya [13]). In the social studies, self-organization is represented as different types of social changes and practices, and finds its expression in such subject areas as civil society and participatory democracy (V. Smirnov, N. Mel'nyk, A. Matiychyk, M. Kel'man), territorial communities (local communities) and local self-government (S. Mokretsov, L. Samoylenko, L. Kazakova, V. Syla, V. Zymohlyad), non-governmental organizations and local selfgovernment authorities (O. Orlovs'kyy, D. Kol'tsova, L. Bezzubko), cooperatives and socially oriented business (Z. Svereda, V. Rossokha), urbanism and bottom-up initiatives (R. Danenberg \& T. Haas, M. Hasanov \& J. Beaumont) and others.

Citizens' initiatives are the «elementary unit» of self- organization, it's the simplest, atomic action aimed to achieve the ordered state. Civil initiative is often identified with citizens' initiatives, although their differences are fundamental. It is common for them that they are interpreted as a mass social movement, as a form of citizens' volition of democratic society, as a form of solving a wide range of problems without the involvement of the state. But the collective dynamic of civil initiatives supposes «... first of all, the spontaneous mass innovation activities of the subjects in the microlevel, who ... unconsciously participate in the transformation of social institutions» $[14$, p. 74]. The unified public, or community is «the subject of micro-level», but not a unique personality. Only a person has a responsibility, and in the case of the unified public it is out of question. The word «community» creates meaningful connotations with «conglomeration» of disorderly, chaotical crowd. Therefore, the public, as a collective subject, a priori cannot be a specialist or an expert in the narrow subject, or in the topics of interdisciplinary and universal nature, which characterize the complex social systems.

The idea of «spontaneous order» of F. von Hayek, one of the founders of classical liberalism, is closely connected to this interpretation of self-organization. According to the researcher, the social «extended» order arises spontaneously, naturally, by the accident, as a result of such laws and mechanisms which characterize the free and open market. It is represented as an integral set of 
individual actions: $\ll \ldots$ an order arising from the separate decisions of many individuals on the basis of different information» $[15, \mathrm{p} .79]$. The question is, if accidental and spontaneous order can be civilized and can maintain the sustainability of social systems. The vitality and humanity are essential characteristics for the social system, and these characteristics are not obligatory in the formation of a spontaneous order. We interpret spontaneously created order as a social chaos with all consequences: with environmental, demographic, economic and social problems, which have spontaneously been developed into global ones. One of these problems since the beginning of 2020 has been the global spread of coronavirus disease (COVID-19). The group of the researchers of London Imperial College under the guidance of N. Ferguson, on the basis of computer simulation, makes a projection of about 510 thousand to 2.2 million deaths from coronavirus in the United Kingdom and the United States, provided that the principles of the laissez-faire market have been taken in the fight against pandemic [16].

Considering the fact that spontaneous activity is at the very edge, and even beyond «the thoughtoriented» action, it can be characterized, according to M. Weber, as a traditional and / or an affective action [17, p. 628]. The individual cannot manage his affective action, and it is not legally accountable. Fear, panic, indignation, and civil deprivation (dissatisfaction), after M. Schulga, are the latent motivation for such actions of the individual [18, $\mathrm{p}$. 159]. The actions of the actors become typical and traditional ones, resulting in their mass effect, where the individual is «collectivized» and «dissolved» in the mass of humanity. Such type of behavior is inert and is expressed in the rootedness of traditional behavior in everyday life, the low capability to change in response to environmental changes, and external conditions.

The civil initiatives can be described as affective response of the population to the actions of other major social actors - government and business. A. Matiychyk lists such well-known forms of initiatives as appealing to the public authorities, public hearings, public debates, social councils at central and local authorities ... signature collection (it is often interpreted as citizens' initiatives), letters to specialized institutions authorities, visiting officials; consultations with the lawyers, public consultations, public expert evaluation, appeals to court, flash mobs on the social networks, posting of campaign information on the own information resources, joining public events within the campaign (protest actions, political performances, round tables, meetings with representatives of specialized institutions) $[19, \quad$ p. 120]. The researchers of self-government problems K. Kul'pina and A. Prudnyk based on empirical data substantiate the idea that appealing to the public authorities as a type of civil initiatives is a palliative. It is not a comprehensive, but only a partial and temporary solution to the issues of 
social regulation. It has masking effect but cannot solve the problems [20].

The affectivity and traditionality of civil initiatives as social actions are the subject of a certain value system, which may be unconscious one. It can be characterized as individualistic, paternalistic and customer-related in a broad sense. «In societies with low standard of living to which Ukraine belongs, there is a danger of substitution the value system for consumer needs and preferences. In these circumstances, there is a feeling of constant dissatisfaction with one's own life, self-depreciation and mass distribution of consumer sentiment in the society», - this has been written in the collective monograph of M.V. Ptukha Institute for Demography and Social Studies of NAS of Ukraine [21, p. 13]. An individual acts as a fighter for his rights without duties, as a critic, an antagonist who protests certain decisions of the authorities but offers no alternatives, and as a consumer of power and public services. Instead, according to R. Inglehart, in well-developed societies, there are values which the researcher calls as the postmaterial ones [22].

In the context of high dynamics of social processes, nonlinearity of consequences of realizing actions («butterfly effect») during transformations and crises, as well as lack of understanding of personal motivation and responsibility, civil initiatives are the social experimentation with random and unpredictable result, therefore, they are destructive. The low organization of such social movements opens the door to multiple opportunities for manipulation in the interests of more organized groups in their struggle for the influence and power.

The elementary self-organized action is civil initiatives, and their interpretation as a spontaneous and uncontrolled action is, probably, a consequence of their consideration in the coordinates of linear thinking and mathematical interdisciplinary means. Such consideration also greatly affect the socio-humanitarian interpretations. In practice, one can observe their limitedness, which provide difficulties to describe the universal character of self-organization in general and in social systems in particular, in its completeness and integrity.

Nonlinearity. Self-organization is interesting because it reflects fundamentally non-linear processes which do not fit into the standard of linear cause-effect logic and functional dependence. Austrian philosopher and researcher of selforganization C. Fuchs states: "The theory of social self-organization has led to a change of scientific paradigms, from the Newtonian paradigm to the approaches of complexity. There is a shift from ... linearity to complexity and multidimensional causality. ... In selforganizing systems one not only finds complex and multidimensional causality, such system is also circular causal» [23, p. 7].

The understanding of selforganizing processes has been significantly supplemented by a new round of development of modern system theory. «However, - as K. Bailey states, - this contemporary 
variety [of social systems theory] is not characterized by functionalism of the 1960s» [24, p. 13]. The ideas of theory of living systems and cybernetics of the second order $(\mathrm{H}$. von Foerster, $\mathrm{H}$. Maturana and $\mathrm{F}$. Varela, N. Luhmann), as well as the theory of complexity and emergence (F. Heylighen, P. Cilliers, F. Eugene Yates, S. Kauffman, M. Woermann, K. Mainzer, Waldrop M. Mitchell, M. Bedau, etc.) have made the significant contributions to the system theory. Thus, M. Woermann, the researcher of complexity and poststructuralism, notes that $\ll \mathrm{H}$. von Foerster defines circularity as the central theme of [the second order] cybernetics» [25, p. 21].

H. Maturana and his colleague F. Varela have made a significant contribution to understanding the fundamental features of living systems and their autonomy: «Key insight was to realize that if the action of the nervous system is determined by its organization, the result is a circular, self-reflexive dynamic» [26, p. 136]. To describe this complex dynamic, the researchers introduce the concept of «autopoiesis». They write: «Living system are organized in a closed causal circular process that allows for evolutionary change in the way the circularity is maintained, but not for the loss of circularity itself... This circular organization defines living system as a unit of interaction and is essential for its maintenance as a unit» [27, p. 9]. So, the system is characterized by self-reflexive dynamic, or the self-reference. It becomes not a point, but a circle with an internal structure.
Circular causality, or interdependence, is a sign of integrity, orderliness, the presence of both direct and inverse relationships in the system, dynamic stability, which appears as some intermediate idealized state of self-repetition of the system between the processes of formation and decay. It can be used as an approximation to the description of normative (target, effective) state of the system, for instance, the social one. Self-organization allows to characterize the movement of matter as causa sui, but not in the classical sense of a prime cause of an infinite chain of causes and consequences (bad infinity), but in the postnonclassical sense of new levels origin from the system itself. In this system the order is an emergent arranged integrity of system elements, and at the same time, their integrity, the new essence, can be an element of another, more complex system.

Emergence, according to A. Malyuta, is «a property or a feature [of a set of elements], which cannot be found in every definite element» [28, p. 13]. It is the emergence of new ordered state of chaos. In social, complex systems that have the properties of living beings and their own specific ones, it is not only a unified movement, or the emergence of certain structures (bureaucracy, social institutions, networks). It is also the universalization, the ordering of different (unique) staff in a complex whole in philosophical sense. In social systems, the qualitative difference between elementary (micro-level) and emergent (macro-level) is 
fundamental. It is a question of social order, ideology, axiosphere.

Self-organization as ordering can be defined as the process of systematization, or systematic implementation (development, movement, implementation of the system). This process can be algorithmized according to current ideas, the system approach of the third generation $[28,29,30]$. The choice of a method in a definite study relies upon the compliance with all 29 requirements formulated by K. Bailey [24] and is suitable for describing the emergence and complexity, selfreference of living and social systems, since this system approach is selfreferential. The means of describing the system notions are also systemic. The usage of this universal method allows to formulate the theory of selforganization of philosophical level of generalization. This fact gives the opportunity to make deductive, reliable conclusions about selforganization in social systems.

According to system-defined approach, self-organization can be defined as the appearance of system elements without the external influence, their stable interactions, resulting in the formation of structure and the emergence of new properties (emergence, integrity) [28].

In social terms, emergence as a whole, unity of the system (community, society) is achieved in different ways: spontaneously, naturally, on the basis of blood affinity, which corresponds to a certain extent, to traditional societies and national states which in the context of global information dynamics, intercultural assimilation experience the identity crisis.

Another way to achieve the unity of complex social systems is their common strategic vision (common goals, ideology, or a «corporate» culture as the dominant value-based characteristic of social system). Common goals can consolidate the populations, structure and eliminate artificial division dictated by institutional, class, ethnic, religious, property, and other differences. Thus, there is no necessity in the choice based on the principle of «or» on the political spectrum if there is a wellformulated and generally accepted goal. The right-wing forces that protect national interests in the international arena, contribute to the development of a society, as well as the left-wing forces contribute to formation of social guarantees to the population.

Besides goal setting, the movement of all the elements of social system in a single direction, there is one more requirement for selforganization at this level. The range of efficient actions is a common system of values for all the elements. V. Budz, a researcher of civil selforganization, states, that if there are some changes in the society, one can also observe them not in politics or economics, morality or law, geopolitics or civilizational norms, ideologies or cultures, but in emotions, feelings, preferences, ideas and values which a person or a big, or small social group possesses, experiences, or begins to lose. The most important structural anthropological element in this 
context are the values that can be interpreted as the unity of all anthropological qualities. «... In this aspect, the values are the expression of the totality of human needs, interests, motives, meanings, worldviews and can be considered as pan-anthropological phenomena beyond which there are no alternative factors of self-organization of social being» [31, p. 16]. Thus, the characteristics of individual values and goals determine the qualities of the deployment of self-organization processes in social systems.

Self-organization in social systems, viewed from the perspective of the third-generation systematic approach, describes the emergence of citizens' initiative as an orderly action. Citizens' initiatives at the height of formulation appeal not to the massless, but to the individual, the citizen. The main difference between citizens' initiatives and civic initiatives is that the first concept has a personal formulation of goals. The formulation of goals implies that the decision-making process is carried out by the initiative citizen himself. The decision is made because of one's own vision of the current situation around local conditions and global trends, the assessment of tasks priority that require the decisions. Independent decision-making not only releases a person from outside influences and paternalistic attitudes, but also imposes responsibility for the consequences of the activities. The presence of the goal and the decision to achieve it are crucial points in understanding citizens' initiatives.
Such meaningful filling of the concept of citizens' initiatives brings it closer to the concept of an entrepreneur, a person capable of action, who does not wait for the directions from above, and is responsible for his activities. An initiative citizen acts as a social entrepreneur whose goals go beyond the narrow limits of economic activity and personal enrichment at any cost, and they are viewed in the broader context of social utility.

Along with the professional activity of the individual, the main employment, highly specialized, as a rule, aimed to reproduce the social system (society), the initiative acts as the overcoming of this order in the direction of the development, evolutionary movement to more perfect state. It is marked by strategic formulation of goals, redefined and implemented by a citizen (citizens), due to the internal resources of social system itself. It allows the citizens' initiatives to be interpreted as an innovation. According to $\mathrm{O}$. Nabatova, one of the «directions of social-innovation activity is the approbation of new forms of selforganization, civic activity, the creation and development of structures of civil society» [14, p. 79].

The generation of an innovative goal (social startup) acts as a creative embodiment of the individual, as an author's idea, a unique intellectual and creative initiative and finding a non-standard solution to a social problem. The presence of one's own macrosocial formulation of goals at elementary level, by the citizens themselves, the preparation of its 
organization and material realization, allows to formalize this elementary level into self-sufficient living integrity (emergence). As a result, the mechanistic nature of structural functionalism in the vision of situation overcomes and, accordingly, this fact gives a chance to overpass it in practice, to increase the level of system organization of social system, and its controllability.

While on the subject of conscious particularity of citizens' initiatives and social entrepreneurship, it needs to be recognized that the Protestant individualistic ethics is no longer sufficient for their value. The society needs another, supra-individual ethics of partnerships, which, in our view, can only be a synthesis of humanistoriented religious and ethical insights. This fact confirms the essence and perspectives of the concept of selforganization as a new non-linear paradigm. It is not only a scientific one, but also philosophical one in terms of generalization and social in its nature.

Conclusions and prospects for further research. The concept of selforganization, with its empirical base qualitatively supply synergetics and its structural-functionalist tendencies in the social-philosophical and macrosocial analysis of social systems. It has been laid down by exact sciences and supplemented by the third-generation systematic approach. It allows to make deductive and more substantiated conclusions about the nature and features of selforganization in social systems. It makes possible to distinguish civil initiatives presented as mass unified affective-traditional dynamics, and citizens' initiatives, presented as a complex, emergent integral process and a unique conscious social action, the distinctive feature of which is individual goals formulation.

The coordination of the initiatives, their organization and ordering are the next steps in the study of selforganization of social systems as a complex, self-referential system. Therefore, the social order «arises» not spontaneously: it is created purposefully and well-organized (selforganized), and it arises as we formulate aims.

It should be emphasized that the prospects of further researches relate to instrumentalizing the notion of «self-organization» as means of understanding macro-social, historical development. Thinking about the past, knowing the features of selforganization, there is an opportunity for adequate understanding of the future, minimizing and eliminating time wasting, material and human resources in social systems, the formation of complex of measures to prevent both natural and social disasters and economic crisis, and purposeful information-force aggression, in which one can observe the essence of self-organization as a social action aimed to order social systems.

\section{Список використаних джерел}

1. Журавлева И., 2011. Социальная самоорганизация как процесс формирования общества знаний (социосинергетический подход). Вестник Московского государственного областного университета. Серия «Философские науки», 4, 25 - 31 . 
2. Negru T., 2018. Self-organization, Autopoiesis, Free-energy Principle and Autonomy. Organon- $F, 25$ (2), 215-243.

3. Закон України, 2001 «Про органи самоорганізації населення». № 2625-III.

4. Haken Hermann, 1997. Self-organization of complex structures: From individual to collective dynamics. Ed. by Frank Schweitzer, Foreword by Hermann Haken. Boca-Raton, London, New-York, Washington, D.C.: CRC Press. URL: https://cutt.ly/br2YzYS.

5. Luhmann Niklas, 1995. Social Systems. Stanford, Stanford University Press.

6. Haken Hermann, 1984. Some Introductory Remarks on Synergetics, Synergetics From Microscopic to Macroscopic Order. Proceedings of the International Symposium on Synergetics at Berlin, July 4-8, 1983. Ed. by E. Frehland. Berlin Heidelberg, Springer-Verlag.

7. Добронравова I., Бевзенко Л., Богата Л., Горбунова Л., Доннікова І., Мєлков Ю. ... Ратніков В., 2016. Досягнення та перспективи синергетичних досліджень у вітчизняній гуманітаристиці. (Круглий стіл). Філософія освіти, 1 (18), 189 - 220.

8. Allen P. M., Engelen G. \& Sanglier M. 1984. Self-Organising Dynamic Models of Human Systems. Synergetics - From Microscopic to Macroscopic Order. Proceedings of the International Symposium on Synergetics at Berlin, July 4-8, 1983. Ed. by E. Frehland. Berlin Heidelberg, Springer-Verlag.

9. Воронкова В. Г., 2009. Синергетична методологія аналізу соціального управління. Гуманітарний вісник Запорізької державної інженерної академї, 36, 26-46.

10.Бевзенко Л., 2014. Социальная интеграция - концептуальные акценты в контексте социосамоорганизационного подхода. Соціальні виміри суспільства 6, 50-69. Доступно: http://nbuv.gov.ua/UJRN/svs_2014_6_6. [Дата звернення 29.03.2020].

11.Андрущенко В., 2006. Організоване суспільство. Проблема організації та суспільної самоорганізачії в період радикальних трансформачій в Украӥні на рубежі століть. Досвід сочіально-філософського аналізу. Київ, Інститут вищої освіти АПН України.

12.Бойченко М. І., 2019. Проблеми суспільної самоорганізації та інституталізації у період радикальних трансформацій в Україні на рубежі тисячоліть: досвід соціальнофілософського аналізу (Рецензія на монографію В. Андрущенка «Організоване суспільство»). Рідна школа Педагогічна преса. Київ, 74-75. Доступно: http://lib.iitta.gov.ua/718551/. [Дата звернення 29.03.2020].

13. Спиця Н. В., 2010. Проблеми методології дослідження процесів самоорганізації суспільства. Гуманітарний вісник ЗДІА, 41, 178-193.

14.Набатова О. О., 2013. Соціально-інноваційна діяльність суспільства як умова людського розвитку, Вісник Національного університету «Юридична академія України імені Ярослава Мудрого», 4 (15), 72 - 84.

15. Hayek von, F. A., 1991. The Fatal Conceit: The Errors of Socialism. The University of Chicago Press.

16. Ferguson N., Laydon D., Nedjati Gilani G., Imai, N., Ainslie, K., Baguelin, M. ... Ghani, A., 2020. Impact of non-pharmaceutical interventions (NPIs) to reduce COVID19 mortality and healthcare demand. (Report 9). Imperial College London. DOI: https://doi.org/10.25561/77482.

17. Вебер М., 1990. Избранные произведения. Пер. с нем. Сост., общ. ред. и послесл. Ю.Н. Давыдова; Предисл. П.П. Гайденко. Москва: Прогресс. (Социологическая мысль Запада).

18.Шульга М., 2018. Збій соціальної матриці. Монографія. Київ: Інститут соиіології НАН України.

19. Матійчик А. В., 2016. Самоорганізація громадянського суспільства як чинник демократичної модернізації політичної системи України. (Дис. канд. політ. наук). Львівський національний університет імені Івана Франка, Львів. 
20. Кульпина К. П., Прудник А. В., 2010. Обращения граждан как паллиатив гражданского участия в самоуправлении и социальной политике. Вестник Института социологии, 1, 154-178.

21.Людський розвиток в Україні: трансформація рівня життя та регіональні диспропорції (колективна монографія), 2012. Відпов. за випуск Л.М. Черенько, О.В. Макарова, за ред. Е.М. Лібанової. У 2-х томах. Київ, Iн-m демографії ma соиіальних досліджень ім. М.В.Птухи НАН Украӥни.

22. Inglehart, R. F., 2018. Cultural Evolution: People's Motivations are Changing, and Reshaping the World. Cambridge, Cambridge University Press.

23. Fuchs Christian, 2002. Some implications of Anthony Giddens' Works for a Theory of Social Self-Organization. Emergence, 4, (3), 7-35.

DOI: https://doi.org/10.1207/S15327000EM0403-03.

24. Bailey, Kenneth D., 1994. Sociology and the New Systems Theory. Toward a Theoretical Synthesis. New York: State University of New York.

25. Woermann Minka, 2016. Bridging complexity and Post-structuralism. Insights and Implications. Springer International Publishing Switzerland.

26. Hayles N. K., 1999. How we became posthuman. Virtual bodies in cybernetics, literature, and informatica. Chicago/London: University of Chicago Press.

27. Maturana Humberto R. and Varela Francisco J., 1980. Autopoiesis and Cognition: The Realization of the Living. Dordrecht, D. Reidel.

28. Малюта А. Н., 1989. Гиперкомплексные динамические системы. Львов, Вища школа.

29. Малюта А. Н., 1990. Закономерности системного развития. Киев, Наукова думка.

30. Малюта А. Н., 1991. Система деятельности. Киев, Наукова думка.

31.Будз В. П., 2019. Панантропологічна парадигма суспільної самоорганізації. Вісник Львівського університету. Серія філософські науки, 23, 12 - 18.

\section{REFERENCES}

1. Zhuravleva, I., 2011. Sotsialnaya samoorganizatsiya kak protsess formirovaniya obschestva znaniy (sotsiosinergeticheskiy podhod). Vestnik Moskovskogo gosudarstvennogo oblastnogo universiteta. Seriya Filosofskie nauki, 4, 25 - 31.

2. Negru, T., 2018. Self-organization, Autopoiesis, Free-energy Principle and Autonomy. Organon- $F, 25$ (2), 215-243.

3. Zakon Ukrainy, 2001 «Pro orhany samoorhanizatsii naselennia». № 2625-III.

4. Haken, Hermann, 1997. Self-organization of complex structures: From individual to collective dynamics. Ed. by Frank Schweitzer, Foreword by Hermann Haken. Boca-Raton, London, New-York, Washington, D.C.: CRC Press. Retrieved from: https://cutt.ly/br2YzYS.

5. Luhmann, Niklas, 1995. Social Systems. Stanford, Stanford University Press.

6. Haken, Hermann, 1984. Some Introductory Remarks on Synergetics, Synergetics From Microscopic to Macroscopic Order. Proceedings of the International Symposium on Synergetics at Berlin, July 4-8, 1983. Ed. by E. Frehland. Berlin Heidelberg, SpringerVerlag.

7. Dobronravova, I., Bevzenko, L., Bohata, L., Horbunova, L., Donnikova, I., Mielkov, Yu. ... Ratnikov, V., 2016. Dosiahnennia ta perspektyvy synerhetychnykh doslidzhen u vitchyznianii humanitarystytsi. (Kruhlyi stil). Filosofiia osvity, 1 (18), 189 - 220.

8. Allen, P. M., Engelen, G. \& Sanglier, M., 1984. Self-Organising Dynamic Models of Human Systems, Synergetics - From Microscopic to Macroscopic Order. Proceedings of the International Symposium on Synergetics at Berlin, July 4-8, 1983. Ed. by E. Frehland. Berlin Heidelberg, Springer-Verlag.

9. Voronkova, V. H., 2009. Synerhetychna metodolohiia analizu sotsialnoho upravlinnia. Humanitarnyi visnyk Zaporizkoi derzhavnoi inzhenernoi akademii, 36, 26-46. 
10. Bevzenko, L., 2014. Sotsialnaya integratsiya - kontseptualnyie aktsentyi v kontekste sotsiosamoorganizatsionnogo podhoda. Sotsialni vymiry suspilstva, 6, 50-69.

11. Andrushchenko, V., 2006. Orhanizovane suspilstvo. Problema orhanizatsii ta suspilnoi samoorhanizatsii v period radykalnykh transformatsii v Ukraini na rubezhi stolit. Dosvid sotsialno-filosofskoho analizu. Kyiv, Instytut vyshchoi osvity APN Ukrainy.

12. Boichenko, M. I., 2019. Problemy suspilnoi samoorhanizatsii ta instytutalizatsii u period radykalnykh transformatsii $\mathrm{v}$ Ukraini na rubezhi tysiacholit: dosvid sotsialnofilosofskoho analizu (Retsenziia na monohrafiiu V. Andrushchenka «Orhanizovane suspilstvo»). Ridna shkola Pedahohichna presa. Kyiv, 74-75. Retrieved from: http://lib.iitta.gov.ua/718551/

13. Spytsia, N. V. , 2010. Problemy metodolohii doslidzhennia protsesiv samoorhanizatsii suspilstva. Humanitarnyi visnyk Zaporizkoi derzhavnoi inzhenernoi akademii, 41, 178-193.

14. Nabatova, O. O., 2013. Sotsialno-innovatsiina diialnist suspilstva yak umova liudskoho rozvytku, Visnyk Natsionalnoho universytetu «Iurydychna akademiia Ukrainy imeni Yaroslava Mudroho», 4 (15), 72 - 84.

15. Hayek von, F. A., 1991. The Fatal Conceit: The Errors of Socialism. The University of Chicago Press.

16. Ferguson, N., Laydon, D., Nedjati Gilani, G., Imai, N., Ainslie, K., Baguelin, M. ... Ghani, A., 2020. Impact of non-pharmaceutical interventions (NPIs) to reduce COVID19 mortality and healthcare demand. (Report 9). Imperial College London. DOI: https://doi.org/10.25561/77482.

17. Veber, M., 1990. Yzbrannыe proyzvedenyia. Per. s nem. Sost., obshch. red. y poslesl. Yu.N. Davbdova; Predysl. P.P. Haidenko. Moskva, Prohress. (Sotsyolohycheskaia mblsl Zapada).

18. Shulha, M., 2018. Zbii sotsialnoi matrytsi. Monohrafiia. Kyiv: Instytut sotsiolohii NAN Ukrainy.

19. Matiichyk, A.V., 2016. Samoorhanizatsiia hromadianskoho suspilstva yak chynnyk demokratychnoi modernizatsii politychnoi systemy Ukrainy. (Dys. kand. polit. nauk). Lvivskyi natsionalnyi universytet imeni Ivana Franka, Lviv.

20. Kulpyna, K. P., Prudnyk A. V., 2010. Obrashchenyia hrazhdan kak pallyatyv hrazhdanskoho uchastyia $\mathrm{V}$ samoupravlenyy y sotsyalnoi polytyke. Vestnyk Ynstytuta sotsyolohyy, 1, 154-178.

21. Liudskyi rozvytok v Ukraini: transformatsiia rivnia zhyttia ta rehionalni dysproportsii (kolektyvna monohrafiia), 2012. Vidpov. za vypusk L.M. Cherenko, O.V. Makarova, za red. E.M. Libanovoi. U 2-kh tomakh. Kyiv, In-t demohrafii ta sotsialnykh doslidzhen im. M.V. Ptukhy NAN Ukrainy.

22. Inglehart, R. F., 2018. Cultural Evolution: People's Motivations are Changing, and Reshaping the World. Cambridge, Cambridge University Press.

23. Fuchs, Christian, 2002. Some implications of Anthony Giddens' Works for a Theory of Social Self-Organization. Emergence, 4, (3), 7 - 35. DOI: https://doi.org/10.1207/S15327000EM0403-03.

24. Bailey, Kenneth D., 1994. Sociology and the New Systems Theory. Toward a Theoretical Synthesis. New York: State University of New York.

25. Woermann, Minka, 2016. Bridging complexity and Post-structuralism. Insights and Implications. Springer International Publishing Switzerland.

26. Hayles, N. K., 1999. How we became posthuman. Virtual bodies in cybernetics, literature, and informatica. Chicago/London: University of Chicago Press.

27. Maturana, Humberto R. and Varela, Francisco J., 1980. Autopoiesis and Cognition: The Realization of the Living. Dordrecht, D. Reidel.

28. Malyuta, A. N., 1989. Giperkompleksnyie dinamicheskie sistemyi. Lvov, Vyischa shkola.

(C) Karalash Yuliia, 2019 
29. Malyuta, A. N. , 1990. Zakonomernosti sistemnogo razvitiya. Kiev, Naukova dumka.

30. Malyuta, A. N., 1991. Sistema deyatelnosti. Kiev, Naukova dumka.

31. Budz, V. P., 2019. Panantropolohichna paradyhma suspilnoi samoorhanizatsii. Visnyk Lvivskoho universytetu. Seriia filosofski nauky, 23, $12-18$.

КАРАЛАШ, Ю. І. - аспірантка кафедри філософії, Житомирський державний університет імені Івана Франка (Україна, Житомир)

E-mail: julia.karalash@gmail.com, ORCID: https://orcid.org/0000-00016537-3543

\section{САМООРГАНІЗАЦІЯ У СОЦАЛЬНИХ СИСТЕМАХ: СУТНІСТЬ, ОСОБЛИВОСТІ ТА ЦЛЬОВА ПРИРОДА}

Актуальність звернення до теми самоорганізації соціальних систем зумовлена, поперше, незавершеністю соціально-гуманітарної теорії цього концепту та, по-друге, об'єктивною необхідністю підвищення рівня організації та впорядкованості соціальних систем, їх керованості шляхом самоорганізації як одного із способів подолання глобальних та локальних викликів. Метою дослідження $\epsilon$ виявлення сутності, особливостей та цільової природи самоорганізації як соціальної дії, що спрямована на впорядкування соціальних систем. У статті обгрунтовується, що міждисциплінарних методологічних засобів, в основі яких математика і котрі задають тон в соціальногуманітарних дослідженнях, недостатньо для виявлення універсальної сутності самоорганізації та специфіки їі розгортання у соціальних системах. Відтак, в якості методологічної основи дослідження сутності та особливостей самоорганізації соціальних систем запропоновано доповнити синергетичні уявлення використанням евристичного потенціалу системного методу третього покоління, що дозволило враховувати напрацювання кібернетики другого порядку, теорій живих систем та емержентності. Стверджується, що формою самоорганізації в соціальних системах, іiі елементарною дією є громадянська ініціатива. Визначено відмінності між громадською ініціативою, яку охарактеризовано як афективну та традиційну несвідому дію, та громадянською ініціативою, емерджентним ефектом якої є власне формулювання цілей індивідом. Це принципово відрізняє іiі від спонтанності ініціатив громадських та дозволяє означити громадянську ініціативу як таку дію, що спрямована на впорядкування соціальних систем. Зроблено висновок, що запропоноване тлумачення самоорганізації соціальних систем та громадянської ініціативи як ії елементу дозволяє глибше зрозуміти механізм підвищення самоорганізованості та керованості соціальними системами, що має особливе значення в умовах необхідності подолання соціально-економічної кризи і пандемії, пошуку відповідей на глобальні виклики, повернення Україні суб'єктності на міжнародній арені з перспективами демократизації всієї соціально-політичної системи та входження в число розвинених країн.

Ключові слова: соціальна система, самоорганізація, циклічна причинність, емержентність, цілі, громадські ініціативи, громадянські ініціативи.

КАРАЛАШ, Ю.И. - аспирантка кафедры философии, Житомирский государственный университет имени Ивана Франко (Украина, Житомир)

E-mail: julia.karalash@gmail.com, ORCID: https://orcid.org/0000-0001$6537-3543$

\section{САМООРГАНИЗАЦИЯ В СОЦИАЛЬНЫХ СИСТЕМАХ: СУЩНОСТЬ, ОСОБЕННОСТИ И ЦЕЛЕВАЯ ПРИРОДА}


Актуальность обращения к теме самоорганизации социальных систем обусловлена, во-первых, незавершенностью социально-гуманитарной теории этого концепта и, вовторых, объективной необходимостью повышения уровня организации и упорядоченности социальных систем, их управляемости путем самоорганизации как одного из способов преодоления глобальных и локальных вызовов. Целью исследования является выявление сущности, особенностей и целевой природы самоорганизации как социального действия, направленного на упорядочение социальных систем. В статье обосновывается, что междисциплинарных методологических средств, в основе которых математика и которые задают тон в социально-гуманитарных исследованиях, недостаточно для выявления универсальной сущности самоорганизации и специфики ее развертывания в социальных системах. Поэтому, в качестве методологической основы исследования сущности и особенностей самоорганизации социальных систем предложено дополнить синергетические представления использованием эвристического потенциала системного метода третьего поколения, что позволило учитывать наработки кибернетики второго порядка, теорий живых систем и эмержентности. Утверждается, что формой самоорганизации в социальных системах, ее элементарным действием является гражданская инициатива. Определены различия между общественной инициативой, которая охарактеризована как аффективное и традиционное бессознательное действие и гражданской инициативой, эмержентным эффектом которой является собственное целеполагание индивидом. Это принципиально отличает ее от спонтанности инициатив общественных и позволяет обозначить гражданскую инициативу как действительно упорядочивающее социальные системы действие. Сделан вывод, что предложенное толкование самоорганизации социальных систем и гражданской инициативы как ее элемента позволяет глубже понять механизм повышения самоорганизованности и управляемости социальными системами, что имеет особое значение в условиях необходимости преодоления социально-экономического кризиса и пандемии, поиска ответов на глобальные вызовы, возвращение Украине субъектности на международной арене с перспективами демократизации всей социально-политической системы и вхождения в число развитых стран.

Ключевые слова: социальная система, самоорганизация, циклическая причинность, эмержентность, цели, общественные инициативы, гражданские инициативы. 